\title{
Kualitas Semen Segar Sapi Rambon Banyuwangi Dalam Pengencer Tris Kuning Telur Dan Susu Skim Kuning Telur
}

\author{
(QUALITY OF FRESH CEMENT OF BANYUWANGI RAMBON CATTLE IN EGG \\ YELLOW TRISTER AND EGG YELLOW SKIM MILK)
}

\author{
Ainun Merta Safitri ${ }^{1 *}$, Trilas Sardjito², Prima Ayu Wibawati ${ }^{3}$, Imam Mustofa ${ }^{2}$, Amung \\ Logam Saputro ${ }^{4}$, Ragil Angga Prastiya ${ }^{2}$ \\ ${ }^{1}$ Bachelor of Veterinary Medicine, \\ ${ }^{2}$ Department of Veterinary Reproduction, \\ ${ }^{3}$ Department of Veterinary Public Health, \\ ${ }^{4}$ Department of Clinic and Animal Hospital, \\ Faculty of Veterinary Medicine, Universitas Airlangga, \\ UNAIR C-Campus Mulyorejo, Surabaya, Jawa Timur, Indonesia, 60115 \\ Telp. (031)5993016, Fax. (031)5993015 \\ *Corresponding author: ainun.merta.safitri-2014@fkh.unair.ac.id
}

\begin{abstract}
Abstrak
Penelitian ini bertujuan untuk mengetahui kualitas semen sapi Rambon Banyuwangi dengan menggunakan dua pengencer yang berbeda, yakni tris kuning telur dan susu skim kuning telur. Metode penelitian ini menggunakan rancangan acak lengkap (RAL). Penelitian ini menggunakan satu ekor pejantan sapi Rambon untuk penampungan semen. Semen ditampung sebanyak sembilan kali untuk dua perlakuan pengencer yaitu P1: semen+tris kuning telur dan P2: semen+susu skim kuning telur. Parameter yang diukur pada penelitian ini adalah motilitas, viabilitas dan abnormalitas spermatozoa. Setiap parameter pada masing-masing perlakuan dibandingkan dengan menggunakan uji T dua sampel. Hasil penelitian ini menunjukkan bahwa P1 lebih mampu mempertahankan motilitas dan viabilitas spermatozoa sapi Rambon Banyuwangi dibanding dengan P2, dimana motilitas P1 yaitu $67,22 \pm 4,41 \%$ dengan kecepatan 3 dan motilitas P2 yaitu 59,44 $\pm 8,46 \%$ dengan kecepatan 2 berbdea nyata $(\mathrm{p}<0,05)$. Viabilitas $\mathrm{P} 1$ adalah $77,44 \pm 3,21 \%$ dan $\mathrm{P} 2$ yaitu $73,56 \pm 3,32 \%$ berbeda nyata $(\mathrm{p}<0,05)$. Tidak terdapat perbedaan yang nyata $(p>0,05)$ terhadap abnormalitas spermatozoa baik primer maupun sekunder sapi Rambon Banyuwangi pada kedua pengencer dimana nilai abnormalitas primer P1 yaitu $0,33 \pm 0,50 \%$ dan P2 $0,22 \pm 0,44 \%$, abnormalitas sekunder P1 yaitu $8,33 \pm 2,17 \%$ dan P2 7,56 $\pm 2,24 \%$. Disimpulkan bahwa media pengencer tris kuing telur dan susu skim kuning telur layak untuk digunakan IB dengan semen segar.
\end{abstract}

Kata kunci: tris kuning telur, susu skim kuning telur, Sapi Rambon, semen segar, kualitas semen

\section{Abstract}

This research aimed to determine the quality of Rambon cattle cement using two different diluents, ie yolk tris and yolk skim milk. The Completely Randomized Design (CRD) was used these research. This study was using one Rambon cattle for cement collection. Cement was collected for nine times and then divided into two different extenders; P1: cement+yolk tris and P2: cement+yolk skim milk. Parameters measured in this study was motility, viability, and abnormality of the sperms. Each parameter at each different diluents was compared using T-test ( $t$-independent sample). The result of this study showed that P1 was more able to maintain the motility and viability of the sperms of Rambon cattle in comparison to P2, whereas the sperms motility using yolk tris was 67,22 $\pm 4,41 \%$ with a 3 score and using yolk skim milk was 59,44 $\pm 8,46 \%$ with a 2 score, there was a significant difference $(p<0,05)$. The viability of the sperms, the viable percentage using yolk tris was 77,44 $\pm 3,21 \%$ and yolk skim milk was 73,56 $\pm 3,32 \%$, there was a significant difference $(p<0,05)$. There was no significant difference in sperms abnormality of Rambon cattle fresh semen in both diluents, whereas the value of each extender to primary abnormalities was 0,33 $\pm 0,50 \%$ in yolk tris and 0,22 $\pm 0,44 \%$ in yolk skim, for secondary abnormalities was $8,33 \pm 2,17 \%$ in yolk tris and 7,56 $\pm 2,24 \%$ in yolk skim milk It can be concluded that the media diluent yolk tris and skim milk-egg yolk feasible to use Artificial Insemination (AI) with fresh cement.

Key words: yolk tris, egg yolk skim, Rambon cattle, fresh cement, cement quality 


\section{PENDAHULUAN}

Sapi Rambon merupakan salah satu sapi lokal yang banyak dikembangkan di masyarakat Kecamatan Glagah Kabupaten Banyuwangi yang berpotensi sebagai penghasil daging sekaligus plasma nutfah (Nugroho dkk., 2013). Pemeliharaan sapi Rambon mudah dan cepat menghasilkan keturunan yang ditunjukkan dengan jarak beranak (Calving interval) yang relatif pendek sehingga mampu menghasilkan pedet hampir setiap tahun, selain itu sapi Rambon Banyuwangi juga memilki daya tahan yang cukup baik terhadap serangan penyakit termasuk jembrana (Efendy dan Lukman, 2016).

Jumlah populasi sapi jantan di Kecamatan Glagah mengalami penurunan dari 183 ekor pada tahun 2005, menjadi 115 ekor pada tahun 2017 (Dinas Peternakan Banyuwangi, 2005; Dinas Pertanian Banyuwangi, 2017). Turunnya jumlah populasi sapi jantan mengakibatkan turunnya kualitas genetik karena terjadinya inbreeding. Sapi Rambon perlu dilestarikan dan menjadi salah satu ikon di Kabupaten Banyuwangi, sehingga dengan terbatasnya jumlah sapi Rambon jantan, perlu dilakukan upaya dalam meningkatkan jumlah populasi ternak dengan menerapkan bioteknologi reproduksi ternak yaitu inseminasi buatan (IB). Salah satu tahapan pada IB yaitu pengenceran. Bahan pengencer yang sudah banyak digunakan yaitu tris kuning telur dan susu skim kuning telur (Ratnawati dkk., 2017).

Pengencer tris kuning telur merupakan larutan buffer yang mengandung asam sitrat yang berperan sebagai penyangga (buffer) dan fruktosa sebagai bahan energi, untuk mencegah perubahan $\mathrm{pH}$ akibat asam laktat serta mempertahankan tekanan osmotik dan keseimbangan elektrolit, sumber energi dan melindungi spermatozoa dari cold shock (Widjaya, 2011).

Susu skim sebagai salah satu bahan pengencer yang mengandung protein, glukosa, air dan lemak yang dapat digunakan sebagai sumber energi bagi spermatozoa. Keuntungan lain dari penggunaan air susu skim sebagai bahan pengencer adalah murah harganya, mudah didapat serta mudah dalam pengamatan secara visual dalam pengujian kualitas secara mikroskopik karena tidak ada gangguan oleh butir-butir lemak yang jumlahnya terlalu banyak (Toelihere, 2000).

Berdasarkan latar belakang diatas, perlu dilakukan penelitian untuk mengetahui kualitas semen segar sapi Rambon Banyuwangi dengan menggunakan jenis pengencer tris kuning telur dan susu skim kuning telur sehinga diketahui jenis pengencer yang baik untuk meningkatkan kualitas semen segar sapi Rambon.

\section{METODE PENELITIAN}

Penelitian menggunakan satu ekor sapi Rambon Banyuwangi jantan umur 4 tahun. Pengambilan sampel semen dilakukan di kandang milik peternak Desa Kemiren Kecamatan Glagah. Pemeriksaan semen dilakukan di klinik Linawati dan laboratorium Instrumen PSDKU Universitas Airlangga kampus Banyuwangi.

Penelitian ini menggunakan Rancangan Acak Lengkap (RAL) dengan 2 perlakuan dan 9 kali pengambilan. Frekuensi penampungan semen dilakukan dua kali dalam seminggu yakni pada hari selasa dan jumat. Semen segar dikoleksi dengan menggunakan teknik vagina buatan dan selanjutnya dievaluasi kualitasnya meliputi pemeriksaan makroskopis (volume, warna, bau, $\mathrm{pH}$ dan konsistensi), mikroskopis (gerakan massa, motilitas, viabilitas, abnormalitas dan konsentrasi spermatozoa) dan uji biologis (uji resistensi). Semen diencerkan dengan menggunakan 2 (dua) jenis pengencer, yaitu tris kuning telur dan susu skim kuning telur. Semen yang telah ditambah pengencer kemudian disimpan pada suhu $5^{\circ} \mathrm{C}$ selama $1-2$ jam. Dilakukan uji kualitas yang meliputi motilitas, viabilitas, abnormalitas primer dan sekunder.

\section{HASIL DAN PEMBAHASAN}

\section{Kualitas Semen Segar}

Hasil pengamatan semen segar sapi Rambon Banyuwangi setelah penampungan selama 
penelitian dapat dilihat pada Tabel 1. Pada Tabel 1 dapat dilihat bahwa sampel semen bewarna putih kekuningan atau krem dengan bau khas sapi. Warna hasil ejakulasi pada masing-masing bangsa sapi berbeda beda, semen sapi pada umumnya bewarna putih sedikit krem atau putih susu atau kekuningan (Kartasudjana, 2001).

Tabel 1. Rataan kualitas semen segar sapi Rambon Banyuwangi

\begin{tabular}{lc}
\hline \multicolumn{1}{c}{ Kualitas } & Rataan \pm SD \\
\hline Makroskopis & $5,11 \pm 0,78$ \\
Volume (ml) & Khas sapi \\
Bau & Putih krem \\
Warna & $6,56 \pm 0,52$ \\
Derajat keasaman (pH) & Kental \\
Konsistensi & \\
& \\
Mikroskopis & ++-+++ \\
Gerakan massa & $81,11 \pm 4,16 / 4$ \\
Motilitas (\%) & $86,78 \pm 4,26$ \\
Viabilitas (\%) & $0,11 \pm 0,33$ \\
Abnormalitas primer (\%) & $5,78 \pm 2,44$ \\
Abnormalitas sekunder (\%) & $3500 \pm 433,01$ \\
Resistensi & $2440 \pm 746,39$ \\
Konsentrasi (juta/ml) & \\
\hline
\end{tabular}

Tabel 2. Kualitas semen pada pengencer tris kuning telur dan susu skim kuning telur

\begin{tabular}{lcc}
\hline \multirow{2}{*}{ Variabel Pengamatan } & \multicolumn{2}{c}{ Pengencer } \\
\cline { 2 - 3 } & Tris Kuning Telur & Susu Skim Kuning Telur \\
\hline Motilitas (\%) & $67,22 \pm 4,41^{\mathrm{b}} / 3$ & $59,44 \pm 8,46^{\mathrm{a}} / 2$ \\
Viabilitas (\%) & $77,44 \pm 3,21^{\mathrm{b}}$ & $73,56 \pm 3,32^{\mathrm{a}}$ \\
Abnormalitas Primer (\%) & $0,33 \pm 0,50$ & $0,22 \pm 0,44$ \\
Abnormalitas Sekunder (\%) & $8,33 \pm 2,17$ & $7,56 \pm 2,24$ \\
\hline
\end{tabular}

Keterangan: Superskrip yang berbeda pada baris yang sama menunjukkan berbeda nyata $(p<0,05)$;

Angka 3 menunjukkan motilitas spermatozoa bergerak cepat;

Angka 2 menunjukkan motilitas spermatozoa bergerak sedang.

Semen memiliki volume 5,11 $\pm 0,78$ masih dianggap normal dengan standar volume semen sapi 3-7 ml. Derajat keasaman $(\mathrm{pH})$ pada sembilan kali penampungan rata-rata berkisar $6,56 \pm 0,52$. Nilai $\mathrm{pH}$ yang mendekati batas normal berkisar 6,4-6,8 (Susilowati dkk, 2010). Konsistensi semen segar yang digunakan pada penelitian ini adalah kental dengan konsentrasi $2440 \pm 746,39$ juta/ml, hal ini menunjukkan bahwa semen tersebut memiliki kualitas yang baik, karena konsentrasi spermatozoa di atas $1000 \mathrm{juta} / \mathrm{ml}$ menunjukkan semen telah memenuhi standar semen sapi jantan (Ratnawati dkk, 2017).
Gerakan massa semen segar sapi Rambon Banyuwangi pada saat penelitian sebesar ++ sampai +++, hasil ini sesuai dengan pendapat Arifiantini dkk (2005) yang menyatakan bahwa pada sapi lokal lainnya seperti sapi Bali memiliki gerakan massa sebesar $++/+++$. Nilai viabilitas $86,78 \%$ dan jumlah abnormalitas primer maupun sekunder yaitu $5,89 \%$ sudah memenuhi standar kualitas semen sapi jantan yaitu viabilitas $>80 \%$ dan abnormalitas <20\% (Ax et al., 2008; Nugroho dkk, 2014). Motilitas memiliki rerata berkisar $81,11 \%$ dengan gerakan bernilai 4 (sangat cepat), nilai ini telah memenuhi standar motilitas kualitas semen segar yang baik karena tidak kurang dari 70\% (Susilawati, 2011). 
Resistensi menunjukkan nilai $3500 \pm 433,01$, nilai ini sudah dapat digunakan untuk inseminasi buatan dengan syarat angka resistensi semen sapi tidak kurang dari 3000 (Susilowati dkk., 2010). Sebelum diberikan pada kelompok perlakuan, pakan perlakuan dan tepung buah hala dilakukan uji proksimat dengan hasil pada tabel 1 . Hasil konsumsi bahan kering dan penambahan berat badan dapat dilihat pada tabel 2 .

\section{Kualitas Spermatozoa pada Pengencer Tris Kuning Telur dan Susu Skim Kuning Telur}

Hasil uji kualitas semen sapi Rambon Banyuwangi menggunakan pengencer tris kuning telur dan susu skim kuning telur yang meliputi pemeriksaan motilitas, viabilitas, abnormalitas primer dan sekunder bisa dilihat pada Tabel 2.

\section{Motilitas}

Hasil pengamatan motilitas semen segar sapi Rambon Banyuwangi setelah mendapatkan perlakuan yaitu pengencer tris kuning telur dengan motilitas $67,22 \pm 4,41 \%$ dengan kecepatan 3 sedangkan untuk susu skim kuning telur $59,44 \pm 8,46 \%$ dengan kecepatan 2. Hasil analisa statistik menunjukkan bahwa penggunaan pengencer tris kuning telur dan susu skim kuning telur berpengaruh terhadap persentase motilitas spermatozoa sapi Rambon Banyuwangi $(\mathrm{p}<0,05)$. Persentase motilitas spermatozoa menggunakan pengencer susu skim kuning telur lebih rendah daripada pengencer tris kuning telur. Perbedaan motilitas antara tris kuning telur dan susu skim kuning telur diduga karena sumber energi dalam susu skim terbatas yaitu glukosa, sedangkan pada pengencer tris kuning telur sumber energi meliputi laktosa dan raffinosa.

Pengencer tris kuning telur memiliki kandungan yaitu tris aminomethane, asam sitrat, laktosa, raffinosa, kuning telur dan antibiotik (Mardiyah, 2001). Laktosa merupakan sumber energi golongan disakarida yang dapat dimetabolisir oleh spermatozoa melalui glikolisis dan /atau siklus krebs untuk menghasilkan energi berupa adenosin trifosfat (ATP). Raffinosa sebagai sumber energi juga akan dimetabolisir melalui jalur glikolisis atau dilanjutkan dengan reaksi asam karboksilat (siklus krebs), sehingga menghasilkan energi berupa ATP yang akan dimanfaatkan oleh spermatozoa dalam pergerakan (Gunawan dan Kaiin, 2008). Tris (hydroxymethyl) aminomethane berfungsi sebagai buffer bersifat basa yang mampu sebagai buffer $\mathrm{pH}$ larutan agar tetap stabil (Hafez, 2000). Asam sitrat pada pengencer tris kuning telur berfungsi sebagai buffer pendispersi lemak pada kuning telur dan berfungsi untuk mempertahankan tekanan osmotik dan keseimbangan elektrolit (Susilawati, 2011). Penelitian Solihati dan Kune (2009) menyatakan bahwa perlakuan pengencer susu skim kuning telur memiliki motilitas yang lebih rendah dibandingkan tris kuning telur disebabkan oleh susu skim yang kurang mampu mempertahankan perubahan $\mathrm{pH}$ akibat terbentuknya asam laktat sisa metabolisme yang menghasilkan energi.

\section{Viabilitas}

Rataan persentase vabilitas spermatozoa sapi Rambon Banyuwangi menggunakan pengencer tris kuning telur sebesar $77,44 \pm 3,21 \%$ dan pengencer susu skim kuning telur sebesar $73,56 \pm 3,32 \%$. Analisis statistik menunjukkan bahwa kedua perlakuan berbeda nyata $(p<0,05)$.

Penurunan angka viabilitas pada susu skim kuning telur dapat terjadi karena adanya perubahan fisik selama proses penambahan pengencer yang mengakibatkan spermatozoa bergesekan dengan globula lemak atau antar spermatozoa sehingga menyebabkan kematian (Rachmawati, 2002). Perbedaan persentase viabilitas pada kedua bahan pengencer juga terjadi karena kandungan kuning telur pada tris kuning telur lebih tinggi yaitu 20\% sedangkan pada susu skim kandungan kuning telur sebesar 5\% sehingga tris kuning telur mampu menyediakan zat makanan yang lebih banyak untuk mempertahankan hidupnya. Kuning telur mengandung lipoprotein dan lesitin yang dapat melapisi membran plasma sel. Kandungan tersebut mampu mempertahankan dan melindungi integritas selubung lipoprotein sel spermatozoa (Mumu, 2009). Lipoprotein akan melindungi sperma dari luar sel yaitu dengan 
jalan meletakkan diri pada membran plasma sperma sehingga sperma terbungkus oleh lipoprotein (Tolihere, 2000). Apabila membran plasma spermatozoa telah mengalami kerusakan, maka metabolisme spermatozoa akan terganggu sehingga akan kehilangan motilitasnya dan mengakibatkan kematian (Yu and Leibo, 2002).

\section{Abnormalitas}

Hasil statistik menunjukkan bahwa persentase abnormalitas primer dan sekunder pada spermatozoa sapi Rambon Banyuwangi pada pengencer tris kuning telur dan susu skim kuning telur tidak berbeda nyata $(p>0,05)$.

Abnormalitas primer terjadi karena adanya kegagalan dalam proses spermatogenesis di tubulus seminiferous, misalnya kepala besar atau kecil, kepala pyriform, kepala kerucut, kepala pendek, lebar, pear shape, dan ekor berganda. Abnormalitas pyriform merupakan salah satu abnormalitas akibat rusaknya kondensasi kromatin selama proses spermiogenesis (AlMakhzoomi et al., 2008). Adapun abnormalitas sekunder terjadi selama proses penyimpanan dan kemungkinan besar disebabkan perlakuaan pada saat pewarnaan dalam proses pembuatan preparat ulas (Garner and Hafez, 2000). Bentuk abnormalitas sekunder meliputi bagian ekor yang melipat, adanya butiran-butiran sitoplasmik proksimal atau distal, dan selubung akrosom yang terlepas dari kepala tanpa adanya ekor, dan ekor yang terputus (Afiati dkk, 2015).

\section{KESIMPULAN}

Kualitas spermatozoa sapi Rambon Banyuwangi pada pengencer tris kuning telur lebih baik dibandingkan susu skim kuning telur pada motilitas dan viabilitas, namun pada abnormalitas primer maupun abnormalitas sekunder relatif sama. Pengencer tris kuning telur dan susu kim kuning telur layak untuk digunakan IB dengan semen segar.

\section{UCAPAN TERIMA KASIH}

Peneliti mengucapkan terima kasih kepada Dinas Pertanian Kabupaten Banyuwangi dan
Prodi Kedokteran Hewan PSDKU Banyuwangi Universitas Airlangga atas fasilitas penelitian.

\section{DAFTAR PUSTAKA}

Afiati, F., Yulnawati, M. Riyadi, R. I. Arifiantini. 2015. Abnormalitas spermatozoa domba dengan frekuensi penampungan berbeda. Prosiding Seminar Nasional Masyarakat Biodiversitas Indonesia. 1(4): 930-934.

Al-Makhzoomi, A., N. Lundeheim, M. Haard, and H. Rodriguez-Martinez. 2008. Sperm Morphogy and Fertility of Progeny-Tested AI dairy bulls in Sweden. Theriogenology, 70: 682-691.

Arifiantini, I., T.L. Yusuf dan N. Graha. 2005. Longivitas dan Recoveryrate Pasca Thawing Semen Beku Sapi Fresian Holstein Menggunakan Bahan Pengencer Yang Berbeda. Buletin Peternakan, 29(2): 53-61.

Ax, R.L., M.R. Dally, B.A. Didion, R.W. Lenz, C.C. Love, D.D. Varner, B. Hafez, and M.E. Bellin. 2000. Semen Evaluation. Lippincott William \& Wilkins. p365-375.

Dinas Pertanian Kabupaten Banyuwangi. 2017. Rekap Populasi Ternak Per Wilayah (Ekor). Dinas Pertanian Kabupaten Banyuwangi. Banyuwangi.

Dinas Peternakan Kabupaten Banyuwangi. 2005. Populasi Sapi Rambon di Kecamatan Glagah Kabupaten Banyuwangi Tribulan III 2005. Dinas Peternakan Kabupaten Banyuwangi. Banyuwwangi.

Efendy, J. dan A. Lukman. 2016. Profil Sapi Rambon Berdasarkan Performans Produksi dan Reproduksi. Banjarmasin. Prosiding Seminar Nasional Inovasi Teknologi Pertanian.

Garner D.L. and E.S.E. Hafez. 2000. Spermatozoa and Seminal Plasma. In: Hafez 
B, hafez E.S.E (eds). Reproduction in Farm Animals. 7th ed. Lippincot William and Wilkins. Philadelphia. p96.

Gunawan, M. dan E.M. Kaiin. 2008. Kualitas Sperma Sapi Beku Dalam Media Tris Kuning Telur dengan Konsentrasi Raffinosa yang Berbeda. JITV, 19(3): 365-375.

Hafez, E.S.E., and B. Hafez. 2000. Reproduction in Farm Animal Seventh Edition. Lippincot Williawms and Wilkins. South Carolina. p96 and 107.

Kartasudjana, R. 2001. Teknik Inseminasi Buatan. Jakarta: Departemen Pendidikan Nasional.

Mardiyah E. 2001. Tehnik Pengenceran Pada Pembuatan Chiling Semen Sapi. Temu Tehnis Non Peneliti, Badan Penelitian dan Pengembangan Departemen Pertanian. Bogor.

Mumu, M.I. 2009. Viabilitas Semen Sapi Simental yang Dibekukan Menggunakan Krioprotektan Gliserol. Journal Agroland, 16(2): 172-179.

Nugroho, E, S., T. Susilawati, and I. Novanti. 2013. Socioeconomic Potential of Indonesian Native Cattle in Supporting Meat Self-Sufficiency in Indonesia. J Livestock Research Rural Develop, 25(11).

Nugroho, Y., T. Susilawati, S. Wahjuningsih. 2014. Kualitas Semen Sapi Limousin Selama Pendinginan Menggunakan Pengencer CEP2 dengan Penambahan Berbagai Konsentrasi Kuning Telur dan Sari Buah Jambu Biji (Psidium guajava). J Ternak Tropika, 15(1): 31-42.

Rachmawati, A. 2002. Motilitas dan Viablitas
Semen Rusa Timor (Cervus timorensis) Menggunakan Pengencer yang Berbeda pada Suhu $5^{\circ}$ C. Jurnal Ilmu-Ilmu Peternakan, 20(2): $1-7$.

Ratnawati, D., N. Isnaini dan T. Susilowati. 2017. Pemanfaatan Casa Dalam Observasi Motilitas Spermatozoa Semen Cair Sapi Madura Dalam Pengencer yang Berbeda. Pasuruan. Jurnal Ilmu-Ilmu Peternakan, 27(1): 80-95.

Solihati, N. dan P. Kune. 2009. Pengaruh Jenis Pengencer Terhadap Motilitas dan Daya Hidup Spermatozoa Semen Cair Sapi Simmental. Seminar Nasional Teknologi Peternakan dan Veteriner. Universitas Padjajaran.

Susilawati, T. 2011. Spermatology. Universitas Brawijaya Press. Malang. Hal.95.

Susilowati, S. Hardijanto., T.W. Suprayogi., T. Sardjito., dan T. Hernawati. 2010. Penuntun Praktikum Insemnasi Buatan. Fakultas Kedokteran Hewan. Universitas Airlangga. Hal.11- 24, 29-30.

Tolihere. 2000. Inseminasi Buatan Pada Ternak. Fakultas Kedokteran Hewan. Institut Pertanian Bogor. Penerbit Angkasa. Bandung. Hal.77-81.

Widjaya, Nilawati. 2011. Pengaruh Pemberian Susu Skim dengan Pengencer Tris Kuning Telur Terhadap Daya Tahan Hidup Spermatozoa Sapi pada Suhu Penyimpanan $5^{\circ} \mathrm{C}$. Sains Peternakan, 9(2): 72-76.

Yu I. and S.P. Leibo. 2002. Recovery Motile, Membrane-Intact Spermatozoa From Canine Epididymides Stored for 8 days at $4^{\circ} \mathrm{C}$. Theriogenology, 57(3): 1179-119. 